\title{
Development and activities of a local beaver Castor fiber albicus population in the vicinity of Dessau, Germany in 1998-2006
}

\author{
Karl-Andreas Nitsche
}

\begin{abstract}
The beaver territories and the beaver activities in the vicinity of Dessau, Germany were observed from 1998 to 2006. Due to the utilisation of the capacities of the natural environment (particularly the ever scarcer food resources) there were no significant increases in numbers found in the investigation area. The population has already exceeded its maximum growth limit. There is no reproduction in some family beaver sites for two or even three years. High-water periods, wild boar (Sus scrofa) activities and anthropogenic interferences (removal of shrubs, tearing down of beaver dams) have made negative impacts on the beaver population. The influence of an area-covering occurrence of American mink (Neovison vison) on beaver reproduction could not yet be verified. The migration of beavers into water bodies close to the city was observed after the flood in 2002. Proposals are made for protective measures that would make a positive impact on the beaver population.
\end{abstract}

KEY WORDS: Elbe beaver, Castor fiber albicus, local population, activities.

Karl-Andreas Nitsche, Akensche Straße 10, D-06844 Dessau, Germany.

\section{Развитие локальной популяции и активность эльбских бобров Castor fiber albicus в окрестностях Дессау, Германия в 1998- 2006 гr.}

\section{Карл-Андреас Нитше}

\begin{abstract}
РЕЗЮМЕ. В течение 1998-2006 гг. в окрестностях г. Дессау (Германия) производился контроль поселений и активности эльбских бобров. Вследствие перенаселенности угодий (в основном из-за оскудения кормовой базы) значительного увеличения популяции зарегистрировано не было. Популяция уже находится у верхнего предела возможной численности, а в некоторых семьях приплода не было два или даже три года подряд. Наибольшее негативное воздействие на эту локальную популяцию оказывают наводнения (в том числе и зимние), роющая активность кабана Sus scrofa и антропогенный фактор (вырубка прибрежных кустарников и разрушение бобровых плотин). Не получено свидетельств влияния на репродукцию бобров обитающей в этих же биотопах американской норки Neovison vison. После зимнего наводнения 2002 г. были зарегистрированы миграции бобров непосредственно в окрестности города Дессау. Даны предложения по природоохранным мероприятиям, которые окажут позитивное воздействие на локальную популяцию.
\end{abstract}

КЛЮЧЕВЫЕ СЛОВА: эльбский бобр, Castor fiber albicus, локальная популяция, активность.

\section{Study area, material and methods}

The investigation area is located in the middle Elbe valley along the rivers Elbe $(16 \mathrm{~km})$, Mulde with tributaries $(25 \mathrm{~km})$, brooks and drainage ditches (full length $60.5 \mathrm{~km}$ ), and backwaters (full length $18.5 \mathrm{~km}$ ) in the vicinity of the town Dessau. The plain, without the town area, is about $56 \mathrm{~km}^{2}$. The height is $56-61 \mathrm{~m} \mathrm{ASL}$. Rivers Elbe and Mulde are lowland rivers with backwaters and river flood plain forests, meadows, and also agriculture areas (pasturages and grasslands). The longterm mean precipitation is about $540 \mathrm{~mm}$. Periodical floods take place in spring and fall. Summer-flood occurs occasionally and it is dependent on strong rain- falls. In the summer and fall of 2005 and 2006, many water bodies were drying up forcing beavers to leave their settlements.

All beaver sites throughout the year were investigated during a period of eight years (1998-2006). All beaver sites were mapped (scale $1: 25000)$ showing typical lodges, dams, and activities. Beavers and their activities were observed during the year (mainly from October to March) and the population size was estimated in some sites without direct observations. All data were listed and compared year by year. The impact of human activities on beaver sites was investigated especially for protection measures in 2004. 
Table 1. Distribution of beaver sites on different waterbodies in the vicinity of Dessau from 1998 to 2006.

\begin{tabular}{|l|c|c|c|c|c|c|c|c|}
\hline & \multicolumn{2}{|c|}{$\begin{array}{c}\text { Rivers } \\
\text { Elbe and Mulde }\end{array}$} & \multicolumn{2}{c|}{$\begin{array}{c}\text { Backwaters, lakes } \\
\text { and ponds }\end{array}$} & \multicolumn{2}{c|}{$\begin{array}{c}\text { Drainage ditches } \\
\text { and brooks }\end{array}$} & \multicolumn{2}{c|}{ Total } \\
\hline year & $\mathrm{n}$ & $\%$ & $\mathrm{n}$ & $\%$ & $\mathrm{n}$ & $\%$ & $\mathrm{n}$ & $\%$ \\
\hline $1998 / 99$ & 10 & 17.0 & 33 & 56.0 & 16 & 27.0 & 59 & 100 \\
\hline $1999 / 00$ & 12 & 21.0 & 31 & 54.0 & 14 & 25.0 & 57 & 100 \\
\hline $2000 / 01$ & 12 & 29.0 & 19 & 45.0 & 11 & 26.0 & 42 & 100 \\
\hline $2001 / 02$ & 15 & 24.2 & 33 & 53.2 & 14 & 22.6 & 82 & 100 \\
\hline $2002 / 03$ & 19 & 30.7 & 25 & 40.3 & 18 & 29.0 & 62 & 100 \\
\hline $2003 / 04$ & 20 & 32.2 & 26 & 42.0 & 16 & 25.8 & 62 & 100 \\
\hline $2004 / 05$ & 21 & 31.0 & 26 & 39.0 & 20 & 30.0 & 67 & 100 \\
\hline $2005 / 06$ & 18 & 26.0 & 28 & 41.8 & 21 & 31.3 & 67 & 100 \\
\hline
\end{tabular}

Table 2. Overview on the notified causalities in 1998-2006.

\begin{tabular}{|l|l|l|c|c|l|l|}
\hline \multicolumn{1}{|c|}{ Date } & $\mathrm{n}$ & \multicolumn{1}{|c|}{ Place name } & Sex & Age & \multicolumn{1}{|c|}{ Cause of death } & \multicolumn{1}{|c|}{ Remarks } \\
\hline 26.09 .1998 & 1 & - & male & ad & beaver bites & - \\
\hline 15.01 .1999 & 1 & road Dessau-Aken & female & ad & roadkill & - \\
\hline 17.03 .1999 & 1 & - & male & ad & $\begin{array}{l}\text { roadkill, liver } \\
\text { carcinoma }\end{array}$ & - \\
\hline 26.09 .1999 & 1 & Wasserstadt & male & ad & roadkill & - \\
\hline 19.05 .2000 & 1 & Ditch, Schillerpark & - & - & $?$ & in decomposition \\
\hline 13.11 .2000 & 2 & Bruchgraben, in sluice & - & ad & starved ? & in decomposition \\
\hline $2000 / 2001$ & 1 & Stillinge-Nord & - & - & $?$ & pers. comm. \\
\hline 19.02 .2001 & 1 & Nixensumpf-Kühnau & - & - & $?$ & Vet.amt., MLU-Halle \\
\hline 01.05 .2001 & 1 & Kleutscher Mühlbach & - & - & $?$ & pers. comm. F. Jurgeit \\
\hline June 2001 & 1 & road Dessau-Aken & - & - & roadkill & pers. comm. R. Hillebrand \\
\hline 12.07 .2001 & 1 & Bruchgraben & - & - & $?$ & in decomposition \\
\hline 28.07 .2001 & 1 & Vorderer Tiergarten & - & - & hard infractions & Vet.amt., MLU-Halle \\
\hline 22.11 .2001 & 1 & Elbe, river km 254 & - & - & $?$ & pers. comm. R.Hillebrand \\
\hline 04.03 .2002 & 1 & road B 184 & - & - & roadkill & in decomposition \\
\hline 29.04 .2002 & 1 & road B 185 Alten & - & - & roadkill & pers. comm. S. Starke \\
\hline 02.08 .2002 & 1 & Scholitzer See & - & - & $?$ & pers. comm. Bühnemann \\
\hline August 2002 & 3 & Dessau & - & - & highwater & in decomposition \\
\hline 05.09 .2002 & 1 & road B 185 Alten & - & - & roadkill & AK Biberschutz \\
\hline 10.01 .2003 & 1 & Küchengarten & - & - & $?$ & pers. comm. K. Kuzcius \\
\hline 11.05 .2003 & 1 & Peisker Brücke & - & - & $?$ & pers. comm. T. Hofmann \\
\hline 04.09 .2004 & 1 & Diepold & - & - & $?$ & in decomposition \\
\hline 11.05 .2005 & 1 & Raumers Stillinge & - & - & heart infractions & Vet.amt., MLU-Halle \\
\hline 22.11 .2005 & 1 & Schwedenwasser & - & ad & roadkill & pers. comm. H.-P. Hinze \\
\hline 30.03 .2006 & 1 & road B 185 Mildensee & female & ad & roadkill & pers. comm. P. Ibe \\
\hline Total & 27 & & & & & \\
\hline & & & & & \\
\hline
\end{tabular}

Designations: in decomposition — no investigations and autopsy; Vet.amt., MLU-Halle — autopsy in the veterinary office (pathology), the Institute of Zoology, Martin-Luther University Halle; pers. comm. - personal communication to the author.

\section{Results}

Beavers inhabited all suitable water bodies in the studied period. The limits of occupied territories often border or overlap, e.g. feeding places at river banks, backwaters, lakes, and ponds were found to be preferred settlement areas (Tab. 1). Currently, both Elbe and Mulde river bank lines have partially insufficient food resources and the annual flooding of their territories have an adverse effect on the beavers because the floods periodically destroy their lodges. During the high-water period, the beavers seek shelter at higher elevations (relief hills or rescue platforms for game animals and beavers) and after water run-off re-settle their territories. There is an increased marking activity during this time (Nitsche, 2001a, b). In 2002 the floods impaired the population only slightly. The exact number of dead beavers during this time is unknown. The beavers were almost exclusively killed due to human activities on the dikes. Further dead beavers finds are listed in Tab. 2. It is difficult to establish the exact number of dead beavers (there is probably a high number of unreported cases, due to unrecorded mortality during floods and ice drift). Losses are swiftly compen- 


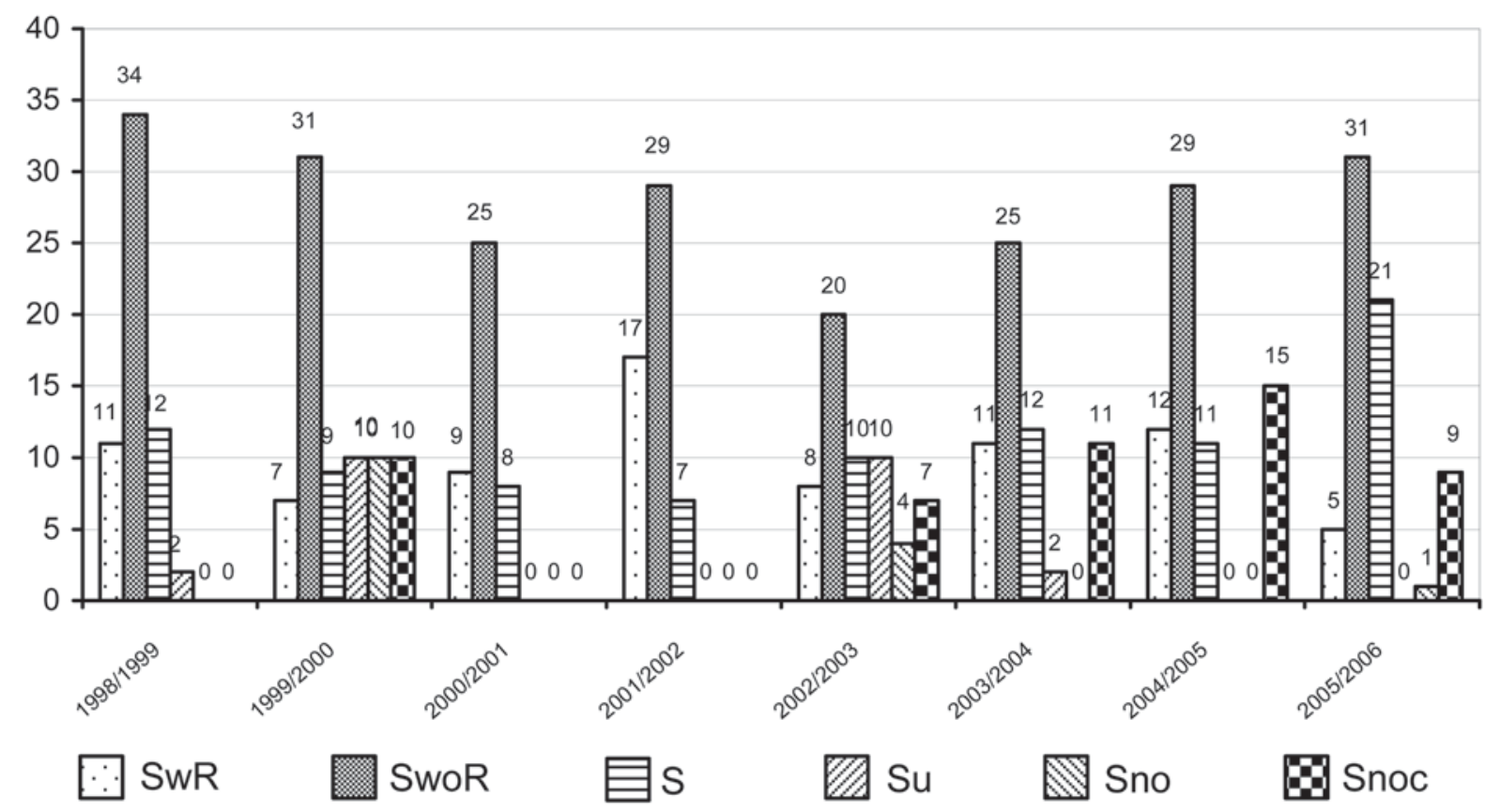

Figure 1. Beaver settlements in the vicinity of Dessau, 1998-2006. SwR - settlements with reproduction (estimated and observed); SwoR — settlements without reproduction (estimated and observed); S — single beaver observed; Su — settlement unknown; Sno — settlement not observed; Snoc — settlement not occupied.
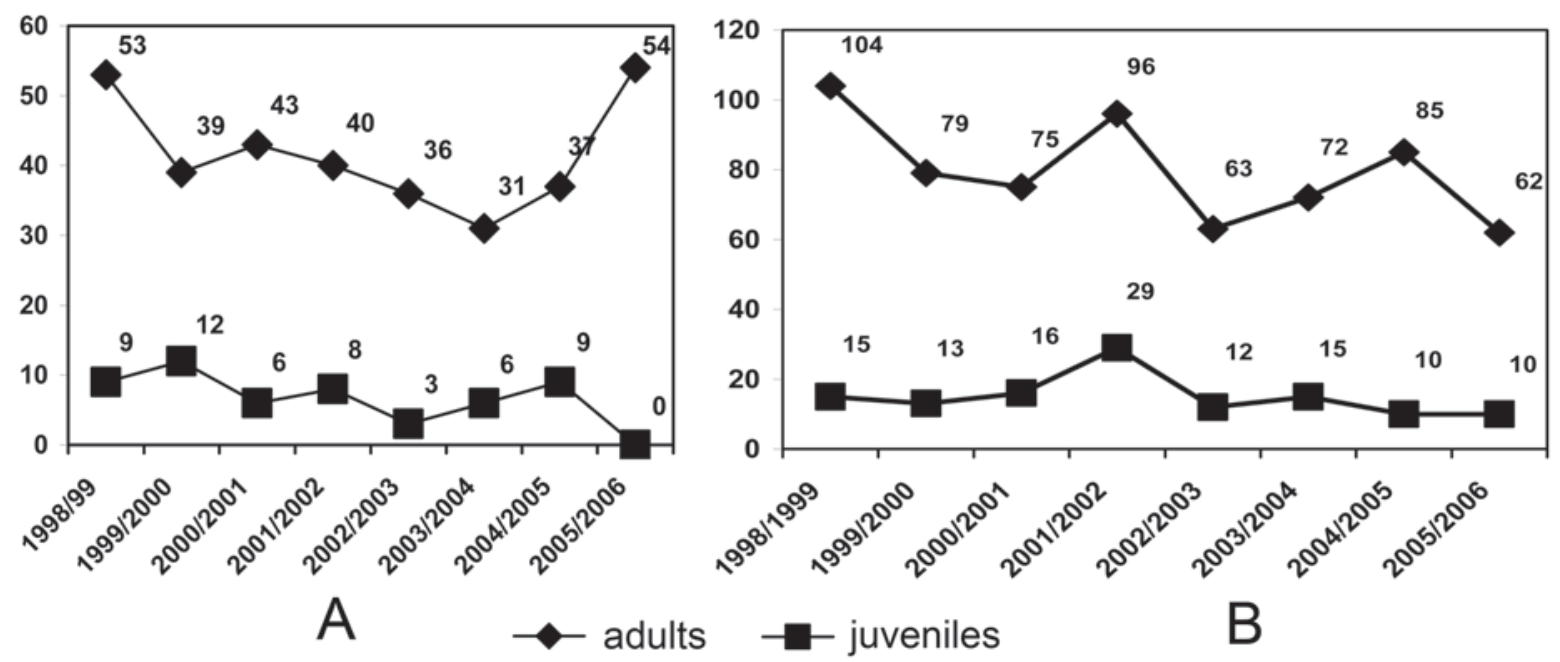

Figure 2. Observed (A) and estimated (B) numbers of adult and young beavers in the vicinity of Dessau, 1998-2006.

sated. High water, especially in winter, forces the beavers to abandon their lodges and build rescue lodges in higher places. The previous territories are re-occupied after flooding or icing (Nitsche, 2003a).

Tab. 1 shows the distribution of beaver sites at different types of water bodies. The number of different beaver sites is shown in Fig. 1. There was no significant difference in the total population between 1998 and 2006: the ratio between observed adult and yearly newborn beavers corresponds to the actual conditions (Fig.
2). Young mortality rate is very high and only ca. 30\% of young beavers are available for reproduction. It was found in some family sites that reproduction already breaks off partially (offspring only every two to three years). Immigration into suboptimal habitats (melioration ditches and receiving bodies), as observed for some 20 years, is occurring only in few cases in the past few years. Several territories at ditches were abandoned due to their limited food resources. The number of occupied lodges, tubes, and of beaver dams are given in the Fig. 3 . 


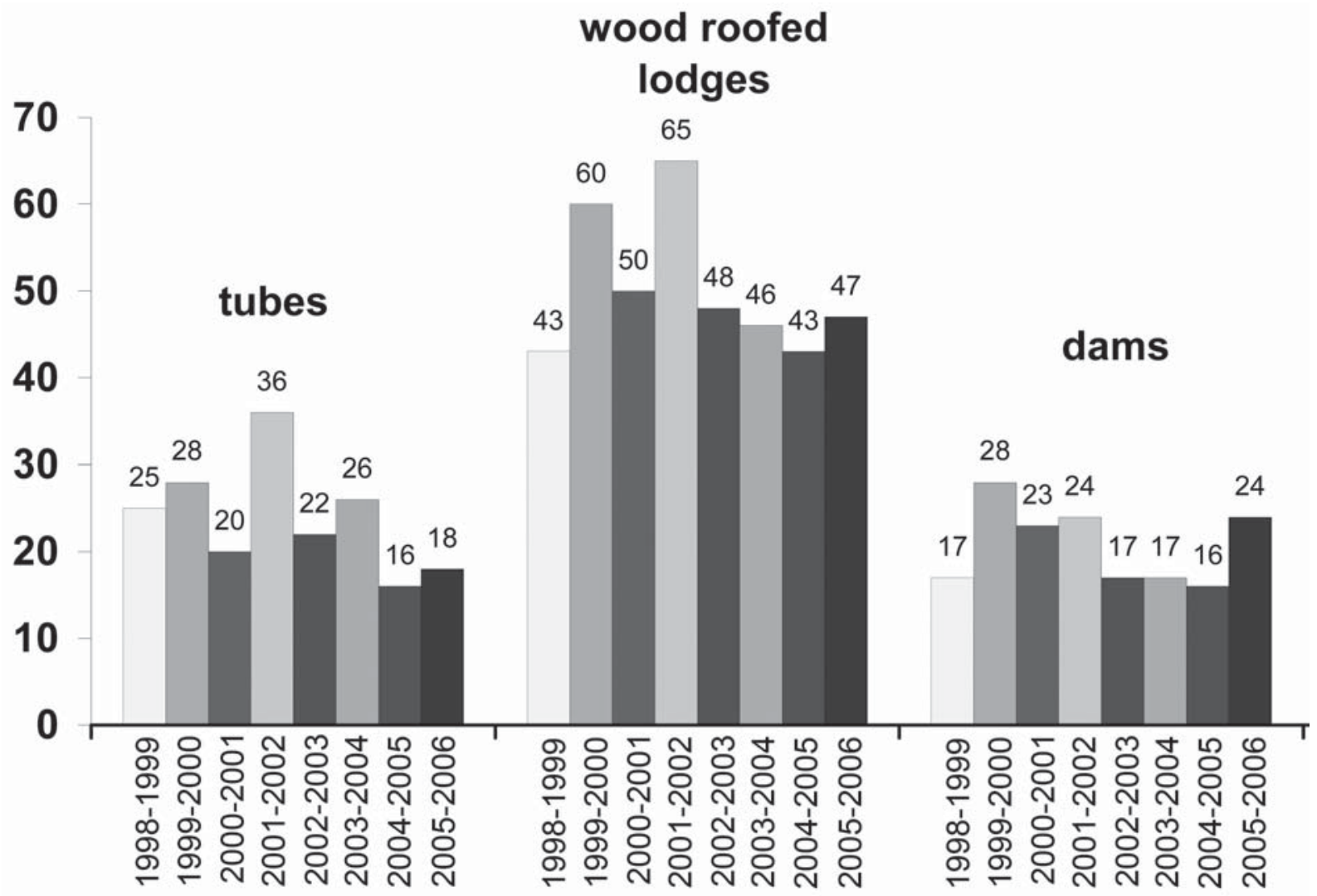

Figure 3. Beaver lodges and dams in the vicinity of Dessau, 1998-2006.

Wild boar Sus scrofa activities make a large impact on the beavers (Nitsche, 1994), which is reflected in altered activity times of the beavers. The extent of influence of American mink Neovison vison on young or new-born beavers could not be established. American mink was found in almost all beaver territories. Studies of anthropogenic activities in 2004 showed very clearly that legal or illegal woodcutting activities contributed to the annihilation of $27 \%$ of the beaver food bases (Fig. 4).

\section{Aspects of beaver protection}

Beavers have never become extinct in the middle reaches of the river Elbe. Today European beaver is a protected species under German and European laws. The lacking food resources presumably influences beaver reproduction in the area around of Dessau. Proposals of large-area willow and other deciduous tress planting in selected areas were submitted to the competent authorities. In addition, it was proposed to erect rescue platforms in suitable places to prevent beavers from damaging dikes during floods. The work of voluntary persons who look after the beavers requires more support by the government authorities. Conflicts often occur when meadows or arable lands are waterlogged as a result of beaver dams that are then often destroyed without using the technical opportunities of drainage. There is only minimum damaging done by cutting trees or fruit orchards. Currently there are no regulations to compensate beaver damages in Saxony-Anhalt, but they are deliberated in cases of hardship.

\section{Conclusions}

It can be stated that the beaver population is unlikely to grow around of Dessau (Nitsche, 2003b). The capacity limits of the beaver territories have been reached. The number of family beaver sites with annual reproduction is limited due to occupied neighbouring territories as well as lacking food resources. Anthropogenic activities are making a partial impact on beaver activities in several areas. The voluntary care of beaver territories should be continued and receive more support by the competent authorities subject to EU legislation (Flora-Fauna-Habitat Guidelines) and German nature preservation legislation. The protection of beaver habitats is of the utmost importance due to their significance as shelter areas for many plant and animal species.

ACKNOWLEDGMENTS. I am thankful for all the help of data sampling, monitoring and information to all honourable assistants of the Beaver work group in Dessau and to the authority for nature protection in 

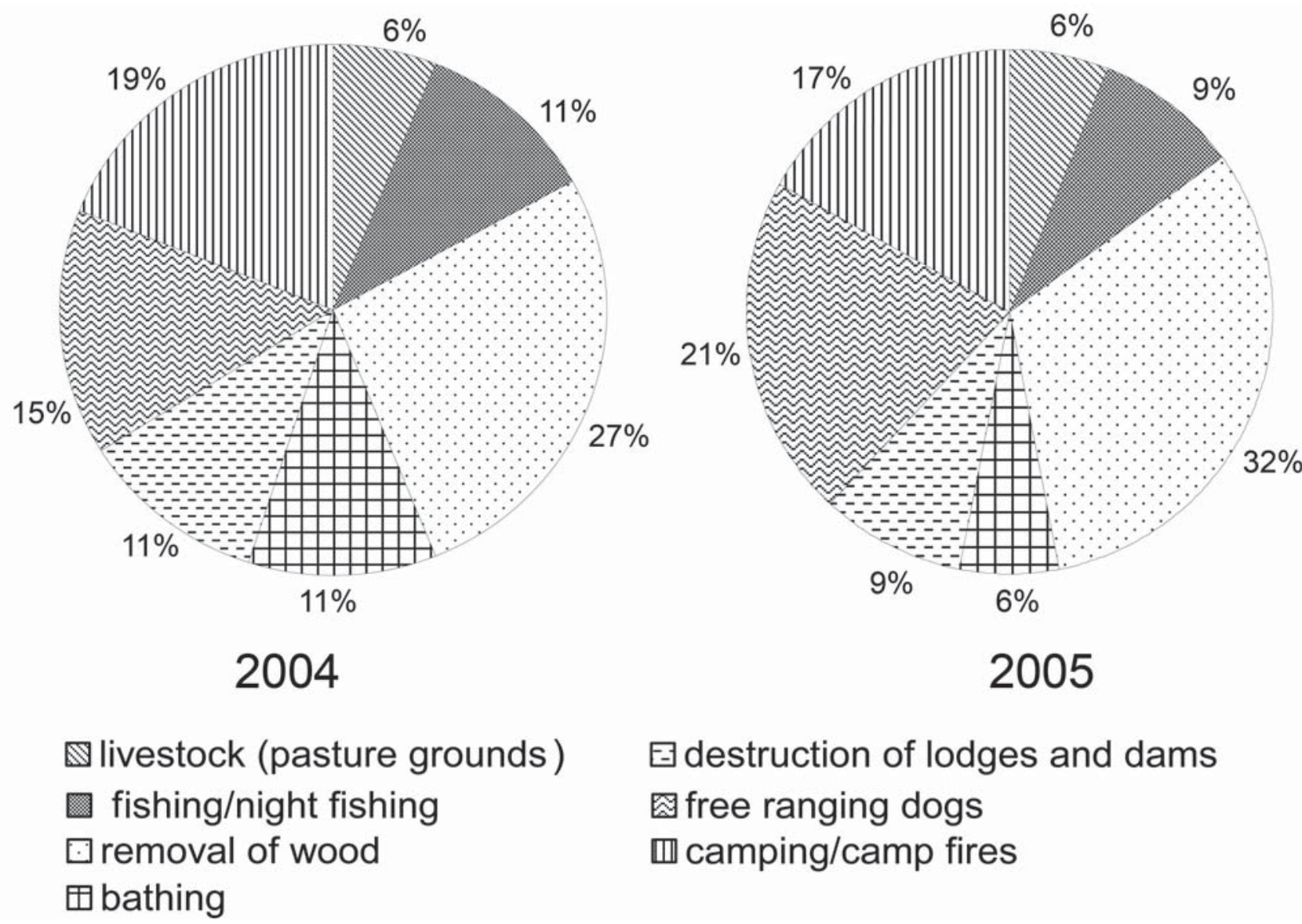

Figure 4. Human activities in beaver sites in the vicinity of Dessau, $2004(n=46)$ and $2005(n=35)$.

Dessau and Dr. D. Heidecke for partial data about the death founds of beavers. I thank Prof. Dr. M. Stubbe for the critical examination of the manuscript.

\section{References}

Nitsche K.-A. 1994. Beziehungen zwischen Bibern (Castor fiber) und Wildschweinen (Sus scrofa) // Säugetierkundliche Mitteilungen. Vol.35. No.2. S.1-5.

Nitsche K.-A. 2001a. Beaver-lodges: long-term observations in a flooded area northeastern near by Dessau // Säugetierkundliche Informationen. Vol.5. Heft 25. S.93-98.
Nitsche K.-A. 2001b. Behaviour of beavers (Castor fiber albicus Matschie, 1907) during flood periods // Czech A. \& Schwab G. (eds.). The European beaver in a new millennium. Proceedings of the $2^{\text {nd }}$ European beaver symposium, 27-30 September 2000, Bialowieza, Poland. Kraków: Carpathian Heritage Society, P.85-90.

Nitsche K.-A. 2003a. Beavers Castor fiber albicus and highwater flood-behaviour and measures // Mammalian Biology - Zeitschrift für Säugetierkunde. Vol.68, Suppl. P.49.

Nitsche K.-A. 2003b. Elbebiber in und um Dessau // Dessauer Kalender. No.47. S.30-37. 